\title{
Biomarkers in Chronic Rhinosinusitis with Nasal Polyp: Personalized Medicine Based on Endotype
}

\author{
Yoonjae Song (iD) and Sung-Woo Cho (iD) \\ Department of Otorhinolaryngology-Head and Neck Surgery, Seoul National University Bundang Hospital, Seongnam, Korea \\ 비용종을 동반한 만성 비부비동염의 바이오마커: 내재형에 기초한 맞춤의료
}

송 윤 재·조 성 우

분당서울대학교병원 이비인후과

\author{
Received April 7, 2019 \\ Revised July 1,2019 \\ Accepted July 9, 2019 \\ Address for correspondence \\ Sung-Woo Cho, MD \\ Department of Otorhinolaryngology- \\ Head and Neck Surgery, \\ Seoul National University \\ Bundang Hospital, \\ 82 Gumi-ro 173beon-gil, \\ Bundang-gu, Seongnam 13620, Korea \\ Tel $+82-31-787-7422$ \\ Fax $+82-31-787-4057$ \\ E-mail iamsungu@gmail.com
}

Chronic rhinosinusitis (CRS) is divided into CRS with nasal polyp (CRSwNP) and CRS without nasal polyp (CRSsNP) according to the presence of a nasal polyp. Some of the CRSwNP patients are relatively well managed without recurrences while others are difficult due to recurrence and refractoriness after surgical or medical treatment. Thus CRSwNP is not a single disease but is rather considered as a disease that has a variety of disease spectrum. Various biomarkers have been proposed to distinguish endotypes of CRSwNP. CRSwNP with high tissue eosinophil infiltration with robust type 2 inflammation (e.g., IL-5) is usually associated with comorbid asthma and is likely to recur. This type of CRSwNP is relatively common in Western countries. However, in Asian countries, CRSwNP is often presented as a heterogeneous disease comprising a mixture of type 1 (e.g., IFN- $\gamma$ ), type 2 and type 3 (e.g., IL-17) inflammation. In Asians, up-regulation of IL-8, IFN- $\gamma$ and associated neutrophilic inflammation is prone to have disease refractoriness. Different underlying inflammatory profile indicates different underlying pathogenesis. Therefore, in the era of precision medicine, treatment should be based upon according to endotype. Korean J Otorhinolaryngol-Head Neck Surg 2019;62(8):427-34

Key Words Biomarkers · Endotype $\cdot$ Nasal polyps $\cdot$ Sinusitis.

\section{서 론}

현재의 분류 기준에 의하면 만성 비부비동염(chronic rhinosinusitis, CRS)은 비용종(nasal polyp)의 유무에 따라 비 용종을 동반한 만성 비부비동염(CRS with nasal polyp, CRSwNP)과 비용종을 동반하지 않은 만성 비부비동염(CRS without nasal polyp, CRSsNP)으로 나뉜다.") 우리나라의 경 우 CRS는 전체 인구의 약 $8.4 \%$ 정도의 빈도로 존재하며, 이 중에서 CRSwNP은 전체 인구의 약 $2.6 \%$ 인 것으로 알려져 있다.2) 대체적으로 $\mathrm{CRSwNP}$ 은 $\mathrm{CRS}$ 의 약 20 50\% 정도를 차

This is an Open Access article distributed under the terms of the Creative Commons Attribution Non-Commercial License (https://creativecommons.org/licenses/by-nc/4.0) which permits unrestricted non-commercial use, distribution, and reproduction in any medium, provided the original work is properly cited.
지하지만, CRSwNP의 경우 치료가 더 어려우며 약물과 수술 적 치료를 하더라고 환자들이 느끼는 증상도 더 심하다. ${ }^{3)}$ 우 리나라에서도 CRSwNP은 굉장히 흔한 질병이기 때문에 이 에 따른 사회 경제적 손실도 상당한 것으로 알려져 있다.

현재까지의 CRS의 분류는 환자가 가지는 표현형(phenotype), 즉 내시경적 검진을 통해 비강 내 비용종을 동반하는 지(CRSwNP) 혹은 동반하지 않는지(CRSsNP)에 따라 이루 어지지만, 똑같은 $\mathrm{CRSwNP}$ 환자라고 하더라고 어떤 환자에 서는 수술 및 약물 치료에 잘 반응을 하는 반면, 다른 어떤 환 자에서는 수술적 치료와 약물 치료를 하더라도 반응하지 않 거나 재발하는 경우가 있어 CRSwNP 안에서도 여러 가지 다 양한 임상양상을 보이고 있다. 이러한 사실을 바탕으로 최근 의 개념은 CRSwNP는 하나의 획일된 질환이 아니라 서로 다 
른 다양한 질병 스펙트럼(disease spectrum)을 가지는 여러 내재형(endotype)으로 구성된 질환으로 보고 있다.4)

표현형에 따른 분류는 "기저 병태생리와 직접적인 연관 없 이 유전자형과 환경과의 상호 작용으로 인해 나타나는 임상 적으로 관찰이 가능한 특징들에 의한 구분”으로 정의할 수 있으며, 내재형에 따른 분류는 “독특한 병태생리 유전학적 기 전에 따른 구분"으로 정의할 수 있다.5)

따라서 여러 내재형으로 이루어진 CRSwNP에 대한 이해 를 하기 위해서는 이를 각각 내재형의 독특한 병태생리 유전 학적 기전 즉 바이오마커(biomarker)를 알아보아야 한다.

이러한 바이오마커는 영상 소견, 내시경 소견과 같은 임상 적으로 나타나는 표현형보다 더 객관적이며, 정량적이어서 실 제 내재된 병태생리를 더 잘 반영하는 것으로 알려져 있다.)

이에 본 종설에서는 $\mathrm{CRSwNP}$ 의 바이오마커에 대한 최신 의 지견에 대해 리뷰하고자 한다.

\section{비용종을 동반한 만성 비부비동염의 바이오마커(Biomarkers in CRSwNP)}

\section{바이오마커의 원천(Source of biomarker)}

일반적으로 바이오마커는 비분비물, 비강 조직검사, 호기 산화질소, 말초혈액 등을 채취하여 얻을 수 있다. 비분비물은 비교적 채취하기가 용이하고, 관찰되는 싸이토카인 수치도 조직 내 발현 정도와 비교적 잘 일치하는 것으로 알려져 있 다. ${ }^{7}$ 비강 조직검사를 통해서는 조직 내 염증(inflammation) 을 나타내는 각각의 구조적 특징, 염증 세포의 구성, 조직 내 싸이토카인의 발현 정도를 비교적 더 구체적이면서 정확하게 측정할 수 있다. 호기 산화질소의 측정은 가장 비침습적이며, 간단하고 빠르게 검사를 시행할 수 있는 방법으로 천식에서 내재형을 구별하는 데에 현재 사용되고 있지만 CRSwNP에 서의 활용은 아직은 잘 밝혀지지 않은 상태이다. 말초혈액에 서의 싸이토카인 혹은 호산구(eosinophil), 특정 림프구(lymphocyte)와 같은 세포를 측정하는 것은 비강 조직을 대변하 는 데에는 한계가 있지만 현재까지 임상적으로 가장 현실적 이고, 경제적인 검사 방법이라 할 수 있다.

현재까지 CRSwNP에서 바이오마커의 발굴은 꾸준히 증 가하고 있으며 천식, 아토피성 피부염과 같은 질환에서 미리 알려진 바이오마커들도 CRSwNP에서 일부 연관이 있는 것 으로 알려져 있다. 최근의 "omics" 기술의 발달로 특정 유전 자 및 단백질로 구성된 후보군들은 더욱 증가하고 있는 추세 이다. 하지만, 질환의 병태생리는 복잡하기 때문에 바이오마 커 후보군들의 각자로 병태생리를 이해하는 것은 어떻게 보 면 전체 큰 틀에서 아주 일부 한 조각만 보는 꼴이기 때문에,
궁극적으로는 여러 바이오마커를 한꺼번에 보는 multiplex panel이 필요할 것으로 사료된다.

\section{조직 내 혹은 혈중 호산구(Tissue or blood eosinophil)}

조직 내 혹은 혈중 호산구(tissue or blood eosinophil) 수 치는 현재까지 가장 잘 알려진 CRSwNP의 바이오마커이다. 서양에서는 $80 \%$ 이상의 CRSwNP에서 조직 내 호산구 침윤 (tissue eosinophilia)을 보이고 있는 반면, 우리나라를 비롯한 중국, 일본 등 동아시아에서의 $\mathrm{CRSwNP}$ 에서는 약 $50 \%$ 정 도에서만 조직 내 호산구 침윤을 보이는 것으로 알려져 있 다. ${ }^{8)}$ 호산구성 비용종을 동반한 만성 비부비동염, 즉 호산구 성 비용종증(eosinophilic CRSwNP)의 경우 glucocorticoid 에 잘 반응을 하는 것으로 알려져 있지만 그렇지 않은 경우, 임상적으로 천식이 동반이 잘 된다거나 수술 후 재발이 더 흔하게 일어나기 때문에, 일반적으로 예후가 더 좋지 않다. ${ }^{9}$ 반면 조직 내 호산구의 침윤이 많지 않은 비호산구성 비용종 증(noneosinophilic CRSwNP), 특히 호중구(neutrophil)의 침윤이 많은 경우에는스테로이드에 대한 반응이 낮은 것으로 알려져 있다. ${ }^{10)}$ 이러한 특징 때문에 많은 임상의들이 CRSwNP 의 분류에 있어서 조직 내 호산구를 사용하고자 하였다.

하지만 아직까지 조직 내 호산구(tissue eosinophilia)에 대 해서는 전세계적으로 공감을 이룰 만한 명확한 기준이 없다. 조직 내 침윤된 호산구는 400배율의 현미경에서 직접 숫자 를 세는 방법[counts per high power field(HPF)]이 있고, 좀 더 직관적이고 주관적일 수 있으나, 침윤된 염증 세포(inflammatory cell) 중 호산구가 차지하는 비율로 하는 기준이 있 다. 또한 조직을 갈아서 조직 내 발현된 eosinophil cationic protein(ECP)/myeloperoxidase(MPO) 비율을 기준으로 하 는 경우도 있다. 최근에 일본의 다 기관 연구에서 밝혔듯이 호산구의 수가 $>70 / \mathrm{HPF}$ 이상일 때 유의한 재발 증가를 보 였는데, ${ }^{9}$ 바이오마커가 질병의 예후를 가장 잘 반영했을 때 가장 의미있는 것이라 생각한다면 이 기준이 좋은 예가 될 것 이다. 하지만 조직 내에서 호산구의 침윤이 균일하게 분포되 어 있지 않고, 똑같은 질환이라도 시간에 따른 변화가 존재하 기 때문에 이들을 항상 감안해야 할 것이다.

\section{제2형 싸이토카인(Type 2 cytokine)}

예전에는 CRSwNP에서 Th2 세포에서 발현 및 분비되는 것으로 알려진 IL-4, IL-5, IL-13과 같은 전통적 Th2 싸이토 카인의 분비가 증가되어 있기 때문에, CRSwNP는 병태생리 적 측면에서 $\mathrm{Th} 2$ 가 중추가 되는 후천적 면역반응(acquired immune response)에 의해 생기는 것으로 여겨져 왔다. 하지 만 Th2 세포뿐만 아니라 innate lymphoid cell type 2(ILC2) 
라는 세포가 CRSwNP에서도 발견이 되었고, ${ }^{11,12}$ 이 세포에 는 상피 세포에서 분비된 싸이토카인(TSLP, IL-25, IL-33) 등에 의해 자극되어 Th2 세포와 매우 동일한 기능을 하는 것 으로 알려지면서 IL-4, IL-15, IL-13 등은 Th2 싸이토카인 보다는 제2형 싸이토카인(type 2 cytokine)으로 불려지기 시 작하였고, 이들이 호산구성 비용종증을 특징짓는 중추적인 바이오마커로 알려져 있다. ${ }^{13)}$

IL-5는 호산구를 조직 내로 모집하는(recruitment) 가장 중 요한 역할을 하는 싸이토카인 중 하나이며, ${ }^{14)}$ 호산구의 침윤 을 결정짓는 중요한 역할을 하는 것으로 알려져 있다. ${ }^{15)} \mathrm{IL}-5$ 가 높게 발현되는 CRSwNP는 병발하는 천식이 있을 가능성 이 높으며, 또한 재발하여 재수술을 해야 하는 확률이 더 높 은 것으로 알려져 있다. ${ }^{15-17)}$ 최근에 시행된 한 연구에 의하면 조직 내 발현되는 특정 싸이토카인의 발현 정도를 가지고 군 집 분석(cluster analysis)을 통하여 확인한 결과 IL-5, IFN-r, IL-17a, TNF-a, IL-22, IL-1b, IL-6, IL-8, ECP, MPO, TGF-b1, IgE, Staphylococcus aureus (S. aureus) enterotoxin specific IgE, albumin의 바이오마커의 조합으로 CRS 를 10 개의 군집으로 내재화(endotyping)를 할 수 있으며, 이 중에서 특히 IL-5가 높게 발현될수록 CRS에서 비용종을 동 반하는 경우가 많고, 이와 더불어 병발하는 천식의 비율이 높 은 것으로 알려졌다. ${ }^{18)}$ 이처럼 $\mathrm{IL}^{-5}$ 는 CRSwNP의 병태생리에 중추적인 역할을 할 것으로 생각되며, 특히 호산구성 비용종 증과 가장 연관된 싸이토카인이라 할 수 있다. 이를 타겟으 로 하는 항 IL-5 의 치료가 일부 CRSwNP에서 중요한 치료 제로 역할을 할 것으로 기대 된다. 현재까지 개발된 항 IL-5 단클론항체로는 reslizumab과 mepolizumab이 있으며, 이 를 사용한 몇몇의 임상시험에서 의미있는 용종 크기의 감소 와 혈중 호산구 수치의 감소를 보였다. ${ }^{19,20)}$ 특히 비즙에서 측 정된 IL-5는 reslizumab에 대한 반응을 예측 할 수 있는 것 으로 알려져 있어 ${ }^{19)}$ 비교적 현실적인 바이오마커로 생각된다.

IL-4와 IL-13도 중추적인 제2형 싸이토카인으로 이 둘은 서로 상승 작용에 의해 $\mathrm{B}$ 세포에서의 $\mathrm{IgE}$ 의 생성을 촉진시 키며, 상피 세포에서 점액 분비를 촉진하는 것으로 알려져 있다. Il-4와 IL-13의 수용체(receptor)는 서로 alpha subunit 을 공유하는데, 이를 target으로 하는 항 IL-4/IL-5 단클론 항체인 dupilumab의 제2상 임상시험에 의하면, 16 주 동안 주 1회 피하로 dupilumab을 접종하였을 때 유의하게 내시경, $\mathrm{CT}$ 소견과 후각을 비롯하여 증상이 호전되었다. ${ }^{21)}$

최근 들어서 상피 세포에서 분비되는 것으로 알려진 IL25, IL-33, TSLP(epithelial derived cytokine)는 Th2 세포, Th2 세포를 활성화시키는 수지상 세포(dendritic cell), 그리 고 ILC2를 자극하여 궁극적으로 제2형 염증반응(type 2 in- flammation)으로 유도하는 역할을 하는 것으로 알려져 있 다. ${ }^{22-25)}$ 이중 IL-33는 조직 내 호중구(neutrophil)을 모집(recruitment)하는 데에도 역할을 하는 것으로 알려졌다. ${ }^{26)} \mathrm{TSLP}$ 는 특히 수지상 세포의 표면에 OX40L의 발현을 증가시키는 데, OX40L는 CD4 T 세포의 OX40 수용체(receptor)와 작용 하여 naive $\mathrm{T}$ 세포를 Th2 세포로 분화를 촉진시키는 것으 로 알려져 있다. 비록 CRSwNP는 아니지만, 천식 환자들을 대 상으로 항 TSLP 단클론항체인 AMG 157을 사용한 제2상 임 상시험에서 $\mathrm{AMG}$ 157을 사용한 군에서 항원(allergen)에 의 해 유도되는 기관지수축(broncho-constriction), 객담 및 혈 중 호산구 수치를 감소시킨 것으로 나타났다. ${ }^{27)}$ 비록 아직까 지 CRSwNP에 관하여 이들 바이오마커를 대상으로 하는 임 상시험은 시행된 바 없지만, IL-25, IL-33, TSLP는 일부 CRSwNP에서 발현이 증가되어 있으며, Lund-Mackay CT score, 혈중 호산구 수치와 유의한 상관관계를 보이고 있고, IL-33의 경우 치료에 잘 반응하지 않는 불응성(recalcitrant) $\mathrm{CRS}$ 에서 증가되어 있는 것으로 알려져 있다. ${ }^{28-30)}$ 또한 CRSwNP 동물모델에서 항 IL-33의 효과가 일부 입증되었기 때문에, ${ }^{26)}$ CRSwNP에서도 효과가 있을 것으로 기대된다.

또 하나의 바이오마커인 periostin은 상피 세포, 호산구, 섬 유아 세포 등에서 분비하는 물질로, 상피하층(subpithelial layer)의 섬유화(fibrosis)에 중추적인 역할을 하는 것으로 알 려져 있는데. 이외에도 periostin은 상피 세포에서의 TSLP 분 비를 촉진시키는 것으로 알려져 있다. ${ }^{31)}$ 이러한 periostin의 분 비는 비만세포(mast cell)에서도 이루어지는데, 이는 IgE mediated signaling에 의해 이루어지는 것으로 알려져 있다. ${ }^{32)}$ 실 제로 천식에서의 혈중 periostin의 농도는 항 $\operatorname{IgE}$ 단클론항체 인 omalizumab에 대한 반응을 예측하게 하는 또 하나의 바 이오마커로 알려져 있는데, ${ }^{33)} \mathrm{CRSwNP}$ 에서도 비슷한 역할을 할 것으로 기대된다.

\section{$\mathrm{B}$ 세포 관련 바이오마커}

$\mathrm{B}$ 세포는 후천 면역에서 중추적인 역할을 하는 면역 세포 로 CRSwNP에서 염증을 지속시키는 중요한 역할을 하는 것 으로 알려져 있으며, CRSwNP의 조직 내에는 증가된 naive $\mathrm{B}$ 세포뿐만 아니라 형질 세포(plasma cell)들이 증가되어 있는 것을 볼 수 있다. ${ }^{34)}$

$\mathrm{CRSwNP}$ 조직 내 많이 발견되는 $\mathrm{B}$ 세포와 연관되어 조직 내에서 면역글로블린(immunoglobulin)이 증가되어 있는 것 을 확인할 수 있는데, 많은 경우가 다수의 B 세포에서 생성 된 다중클론성항체(polyclonal antibody)로 특정 항원이 잘 알려지지 않는 반면, 일부에서는 자가항원특이항체(autoantigen-specificantibody) $\operatorname{IgG}$ 와 $\operatorname{IgA}{ }^{35)}$ 혹은 staphylococcal 
enterotoxin 특이 $\mathrm{IgE}$ 등이 높게 발견된다. ${ }^{36)}$ 특이하게도 이 러한 면역글로블린은 주로 혈액에서는 높게 측정되지 않고, 비용종 조직 내에서 높게 측정된다. 특히 조직 내 staphylococcal enterotoxin 특이 IgE가 발견되는 경우, 조직 내에서 total $\mathrm{IgE}$ 의 수치가 높게 나오는데, ${ }^{37)}$ 이는 enterotoxin의 $\mathrm{su}^{-}$ perantigen 작용으로 B 세포의 다클론성 면역글로블린의 합 성을 일으켰기 때문일 것으로 생각된다(Fig. 1). 뿐만 아니라

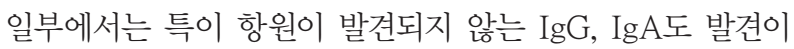
되기도 한다. ${ }^{38)}$ 따라서 $\mathrm{CRSwNP}$ 의 병태생리에 $\operatorname{IgE}, \operatorname{IgG}, \operatorname{IgA}$ 가 모두 관여를 할 것으로 생각되며, 비용종 조직 내 많은 세 포에서 $\mathrm{Fc}$ 수용체(receptor)가 발현되어 있고, 조직에 축적된 면역복합체(immune complex)가 보체에 의한 케스케이드 경로(cascade pathway)를 활성화시킨다. ${ }^{39)}$

Omalizumab은 유리된 $\mathrm{IgE}$ 에 강하게 달라붙어 $\mathrm{IgE}$ 가 crosslinking되는 현상을 방지하는 단클론성항체로 주로 중 층천식(severe asthma)의 치료제로 사용된다. 한 무작위 임상 시험(randomized controlled trial)에 의하면 중증 천식 환자 중 CRSwNP가 있는 환자가 이로 치료받으면 polyp의 크기 가 유의하게 줄어들며, CT상에서 부비동의 혼탁도(opacity)를 유의하게 줄이는 것으로 확인되었으며 이러한 효과는 전신 아토피에 상관없이 나타나는 것으로 알려졌다. ${ }^{40)}$

$\mathrm{B}$ cell activating factor of the TNF family(BAFF)는 최근
에 발견된 TNF superfamily 중 하나로, B 세포의 생존(survival), 증식(proliferation), 그리고 성숙(maturation)에 중요한 역할을 하는 것으로 알려져 있다. BAFF는 transmembrane activator and CAML interactor(TACI)와 결합하여 B 세포 의 class-switch recombination 및 이로 인한 $\operatorname{IgA}$ 의 생성에 중요한 역할을 한다. 비록 CRSwNP의 병태생리에서 $\operatorname{IgA}$ 가 어떠한 역할을 하는지 아직 자세히 알려지진 않았지만 호산 구에서의 탈과립화(degranulation)를 촉진시키는 것으로 알 려져 있다. BAFF는 CRSwNP에서 발현이 높아져 있고, 이 와 연관되어 $\mathrm{B}$ 세포의 표면 항원인 CD20과 $\operatorname{IgA}$ 가 증가되었 는데, ${ }^{41)}$ 이처럼 $\mathrm{BAFF}$ 에 의한 B 세포의 활성화와 $\operatorname{IgA}$ 생성에 의한 호산구의 탈과립이 CRSwNP의 병태생리에 중요한 역 할을 할 것으로 생각된다.

\section{동양형 비용종증에서의 바이오마커}

대부분의 바이오마커는 호산구성 비용종증이 대부분인 서양 환자들을 대상으로 시행한 결과이다. 따라서 병태생리가 다르다고 생각되는 동양형 비용종증에 대한 바이오마커를 찾아보려는 노력이 필요하다고 할 수 있다. 동양형 비용종증 은 서양 환자들에서 보이는 임상양상이 서로 다른 것으로 알 려져 있다. 한 다국적 연구에 의하면 동일한 방법으로 비용 종의 면역학적 특징을 분석한 결과 서양의 경우 제 2 형 염증

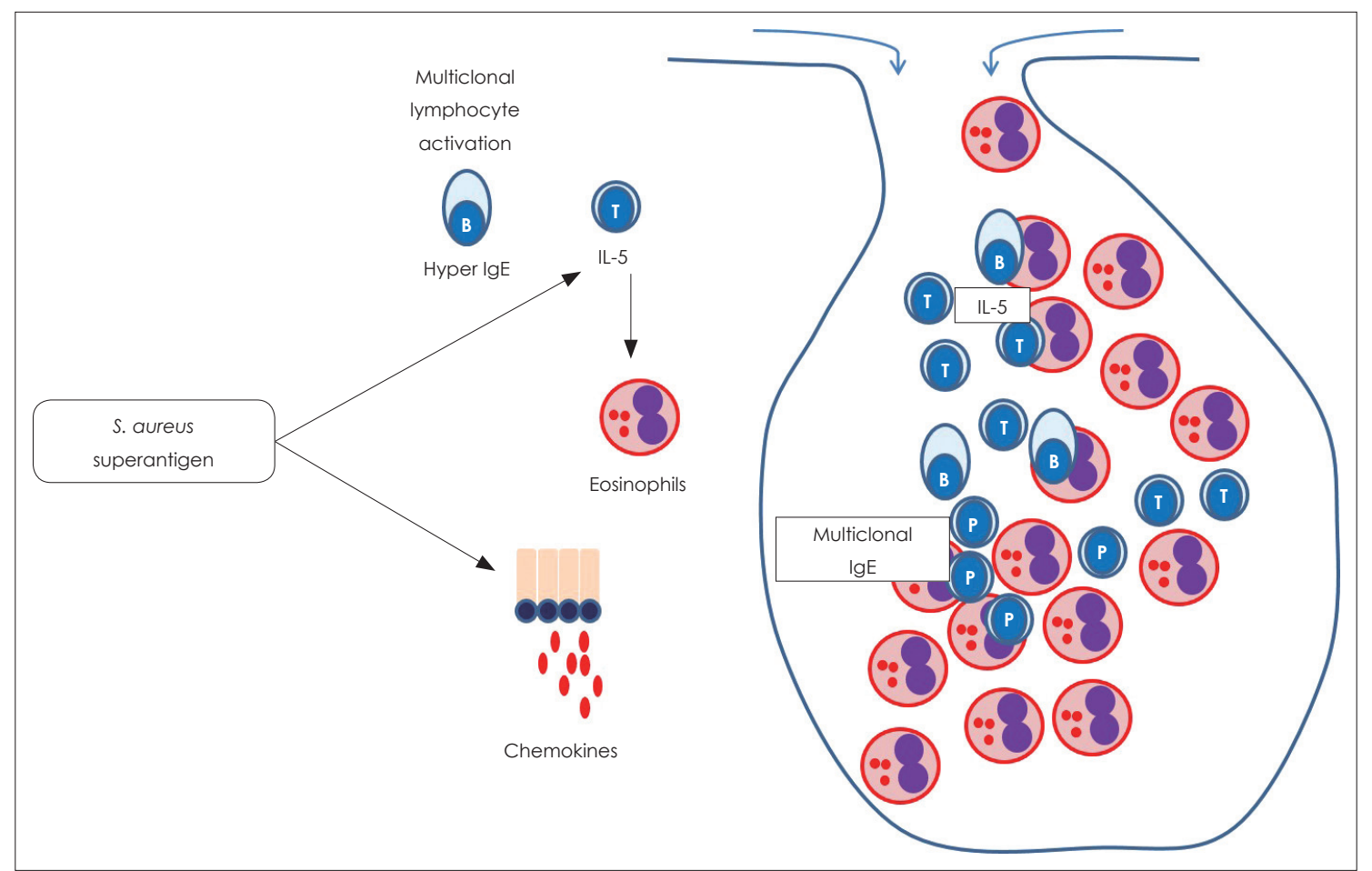

Fig. 1. Activation of B cells and T cells by superantigen from $S$. aureus. Activated B cells produces polyclonal IgE antibodies which accumulates in the polyp tissue. One of the actions of accumulated immune complex is the activation complement cascade pathways. Activated T cells produces IL-5 which further recruits eosinophils. S. aureus: staphylococcus aureus. 
반응으로 치우쳐진 반면, 동양인의 경우, CRSwNP 환자 개개 인에서는 특정 염증 패턴을 볼 수 있지만, 환자들을 전체적 으로 본다면 특정 염증 패턴으로 치우쳐 있다기보다는 제1 형, 제2형, 제 3 형 염증반응의 다양한 패턴을 보이고 있다. ${ }^{42)}$ 제1형 및 제3형 염증반응은 각각 제1형 및 제3형 싸이토카인 이 많이 활성화되어 있는 상태로, Th1, Th17 세포뿐만 아니 라, 이들 세포들과 비슷한 기능을 하는 ILC인 ILC1(Th1) 및 ILC3(Th17)가 발견됨으로써 T 세포 및 ILC에 의해 IFN- $\gamma$ (제1형 싸이토카인), IL-17(제3형 싸이토카인) 등이 높아져 있 는 상태를 의미한다. 동양에서 비교적 흔하게 발병하는 비호 산구성 비용종증에서는 제2형 염증반응이 적은 반면, IL-17 의 발현이 상대적으로 많은 것을 확인할 수 있는데, IL-17은 호중구를 조직 내로 끌어들이고 활성화하는 것으로, 이는 동 양인의 비호산구성 비용종증에서 비교적 스테로이드의 반응 성이 떨어지는 것을 설명할 수 있다. 하지만 동양인에서 IL-17 과는 별개로, IL-8, IFN- $\gamma, \mathrm{GM}-\mathrm{CSF}$, 그리고 조직 내 호중 구의 침윤이 많은 경우 치료에 불응하는 경우가 많다. ${ }^{43)}$

하지만 Tomassen 등 ${ }^{18)}$ 의 연구에서 처럼 동서양을 떠나서 $\mathrm{CRS}$ 는 이분법적(dichotomic)인 질환이 아니라 다양한 내재형 (endotype)으로 이루어진 복잡한 질환이고, 인종적 차이에 의 해(아마도 genetic background) 내재형의 분포가 서양인과 동 양인이 차이가 있을 것으로 보이며(Fig. 2), 실제로 인종과는 상관없이 각자의 내재형이 있고, 이와 관련된 표현형(phenotype)이 일관되게 유지되는 것으로 알려져 있다. ${ }^{42)}$ 따라서 동 양형의 특정 바이오마커라고 하기보다는 동양인에서 비교적 흔하게 보이는 비호산구성 비용종증의 경우, 조직 내 염증반 응이 제1형 및 제 3 형 싸이토카인이 높아진 특징을 보이는 경 우로 보아야 할 것이며, 이에 대해서는 IL-17a, IL-22와 같은

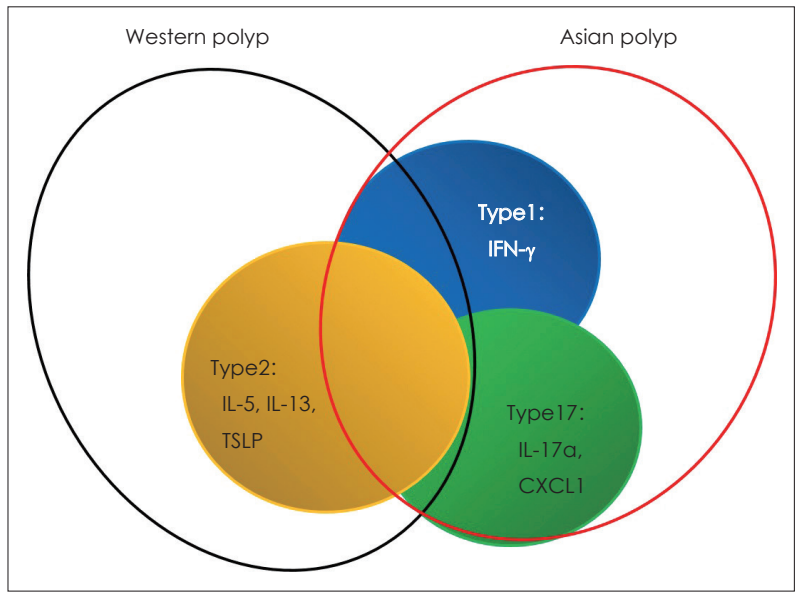

Fig. 2. Endotype distribution among Western and Asian polyps. Both are mixture of type 2 and 1/17 inflammation. Western polyps are more shifted towards type 2 inflammation, while as Asian polyps are more shifted towards type 1/17 inflammation.
물질들을 바이오마커로 생각할 수 있으며, 이들에 대한 단클 론항체가 치료를 생각해 볼 수 있을 것이다. 지금까지 이들 싸 이토카인에 대한 몇몇의 단클론항체들이 있으며 현재 임상 시험 중인 것으로 알려져 있지만 아직까지 이들의 효과가 확 인되지는 않았다.

\section{임상적으로 쉽게 얻을 수 있는 바이오마커}

지금까지 언급한 바이오마커와 이들은 단클론항체를 Table 1 에 정리하였다. 이들 대부분은 혈중, 비즙, 혹은 조직 내에서 직접 측정한 것들이다. 하지만 실질적으로 임상적으로 적용 하는 데에 있어 비즙 혹은 조직 내 단백질을 직접 측정하는 데는 한계가 있다. 따라서 조직 내 단백질 단계에서의 바이오 마커를 잘 반영하는 임상적인 지표를 찾고자 하는 노력이 있 어왔고, 대표적인 것이 Japanese clinical scoring study(JES$\mathrm{REC}$ )이다. ${ }^{9)}$ 이는 비교적 실제 임상 현장에서 많이 평가되는 항목들로 이루어져 있다. JESREC score는 1) CT에서의 eth$\mathrm{moid} / \mathrm{maxillary}(\mathrm{EM})$ ratio, 2) 혈중 호산구 비율, 3) 천식 유 무, 4) aspirin을 비롯한 NSAID에 대한 과민성 유무에 따라 수술 후 질환의 재발 위험도를 기반으로 하는 scoring system 으로 점수에 따라 non-eosinophilic CRS(non-ECRS), mild $\mathrm{ECRS}$, moderate ECRS, severe ECRS로 구분할 수 있다. $\mathrm{Se}-$ vere ECRS일수록 수술 후 재발(recurrence)과 치료에 대한 불응도(refractoriness)가 높은 것으로 알려져 있다. JESREC

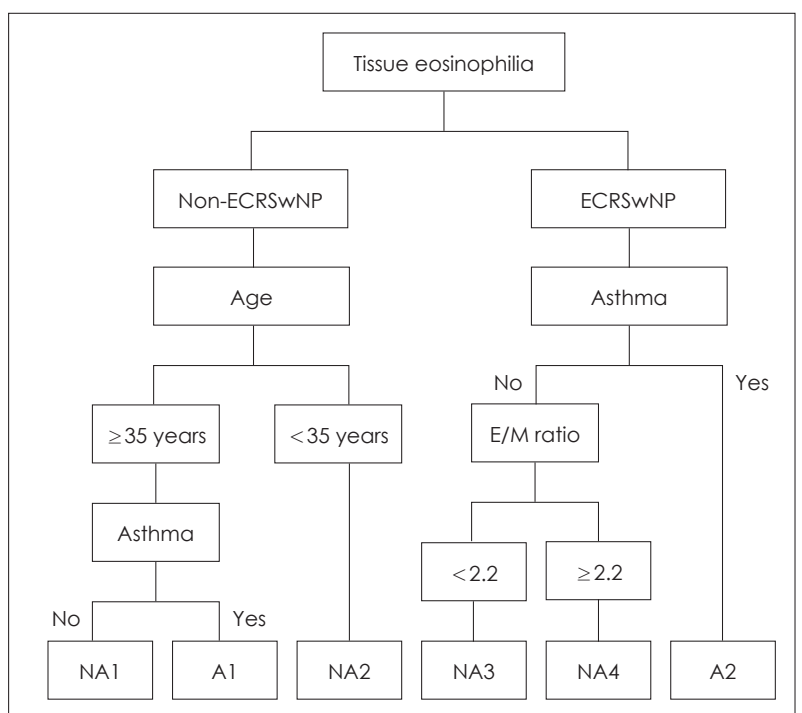

Fig. 3. Algorithm for classification of polyps by using routinely available clinical markers. Patients are classified into 1 of 6 clusters based on the presence of tissue eosinophilia, presence of asthma, age, and E/M ratio. A1: asthmatic, non-eosinophilic polyp, A2: asthmatic eosinophilic polyp, NA1: non-asthmatic non-eosinophilic polyp with older age, NA2: non-asthmatic non-eosinophilic polyp with younger age, NA3: non-asthmatic eosinophilic polyp with lower E/M ratio, NA4: non-asthmatic eosinophilic polyp with higher E/M ratio. E/M: ethmoid/maxillary. 
Table 1. Representative biomarkers in chronic rhinosinusitis with nasal polyp and their targeting monoclonal antibodies

\begin{tabular}{lcl}
\hline & Representative biomarker & Monoclonal antibody \\
\hline Epithelial derived cytokine & TSLP, IL-25, IL-33 & Tezepelumab (TSLP) \\
Type 2 cytokine & $\mathrm{IL}-4 / \mathrm{IL}-13$ & Dupilumab (IL-4/IL-13) \\
& $\mathrm{IL}-5$ & Mepolizumab (IL-5) \\
& & Reslizumab (IL-5) \\
& & Benralizumab (IL-5) \\
B cell associated & BAFF, IgE & Omalizumab (IgE) \\
Type $1 / 17$ cytokine & IFN- $\gamma$, IL-17, IL-22 & Investigational drug only \\
\hline
\end{tabular}

BAFF: B cell activating factor of the TNF family

score는 면역학적으로도 검증이 되었는데, severe, moderate 일수록 IL-5, 1L-13과 같은 제2형 싸이토카인이, non-ECRS, mild ECRS일수록 IFN- $\gamma$, IL-17a, CXCL1 등 제1형/제3형 싸이토카인이 증가되어 있다. ${ }^{44)}$

비슷한 연구가 국내에서도 있었는데, ${ }^{45)}$ 이 연구에서는 CRSwNP 환자들의 임상적인 특징 즉 CT에서의 Lund Mackey score, E/M ratio, 조직 내 호산구 침윤 정도, 천식 유무, 그리고 환자의 수술 당시 나이를 기반으로 CRSwNP를 분류 하였다(Fig. 3). 조직 내 호산구 침윤 정도는 임상적으로 쉽게 구해지도록 현미경으로 직접 호산구의 개수를 세는 방법보다 는 전체 침윤된 염증 세포 중에서 호산구가 $20 \%$ 이상인 경 우로 정의하였는데, 이는 비교적 쉽게 병리과 의사의 직관에 의해 정해진다. 이 연구에 의하면 1) 천식과 동반된 호산구성 비용종증, 2) 천식이 없더라도 $\mathrm{E} / \mathrm{M}$ ratio가 2.2 이상인 호산 구성 비용종증, 3) 나이가 비교적 젊은 비호산구성 비용종증 의 경우 재수술의 빈도가 비교적 높다.

$\mathrm{CRSwNP}$ 는 여러 가지 내재형(endotype)으로 구성된 복합 적인 질환으로 각각 내재형에 대한 바이오마커에 대하여 알 아보았다. 서양형 비용종증에서는 호산구성이 많은 반면 동 양형 비용종증에서는 비호산구성이 많은 것으로 알려져 있 다. 호산구성 비용종증은 제2형 염증이 많이 발현되어 있지 만, 비호산구성 비용종증은 제2형 염증은 적은 반면 상대적 제 1 형 혹은 제 3 형 염증반응이 증가되어 있다. 하지만, 각각의 인종에 따라 내재형이 서로 다르다고 표현하기보다는 여러 가지 내재형의 분포가 인종마다 다르다고 해석하는 것이 더 합당하다. 각각의 내재형은 이를 특징하는 표현형(e.g., 동반된 천식 유무)을 가지고 있다. 이러한 내재형을 바탕으로 개인 맞춤형 치료(targeted therapy)가 가능할 것으로 보인다. 하 지만 실제로 일관되고, 임상에서 쉽게 얻어지는 검사 방법을 통해 확인할 수 있는 바이오마커를 찾는 것 또한 중요할 것 이다.

\section{Acknowledgments}

This work was supported by the National Research Foundation of Korea (NRF) grants funded by the Korea government (MSIP)
(no.2019R1C1C1009886).

\section{ORCID}

Sung-Woo Cho https://orcid.org/0000-0003-0827-4471

Yoonjae Song https://orcid.org/0000-0002-6601-0813

\section{REFERENCES}

1) Fokkens WJ, Lund VJ, Mullol J, Bachert C, Alobid I, Baroody F, et al. EPOS 2012: European position paper on rhinosinusitis and nasal polyps 2012. A summary for otorhinolaryngologists. Rhinology 2012;50(1):1-12.

2) Ahn JC, Kim JW, Lee CH, Rhee CS. Prevalence and risk factors of chronic rhinosinusitus, allergic rhinitis, and nasal septal deviation: Results of the Korean National Health and Nutrition Survey 20082012. JAMA Otolaryngol Head Neck Surg 2016;142(2):162-7.

3) Stevens WW, Schleimer RP, Kern RC. Chronic rhinosinusitis with nasal polyps. J Allergy Clin Immunol Pract 2016;4(4):565-72.

4) Akdis CA, Bachert C, Cingi C, Dykewicz MS, Hellings PW, Naclerio RM, et al. Endotypes and phenotypes of chronic rhinosinusitis: A PRACTALL document of the European Academy of Allergy and Clinical Immunology and the American Academy of Allergy, Asthma \& Immunology. J Allergy Clin Immunol 2013;131(6):147990.

5) Agache I, Akdis C, Jutel M, Virchow JC. Untangling asthma phenotypes and endotypes. Allergy 2012;67(7):835-46.

6) Taylor DR. Using biomarkers in the assessment of airways disease. J Allergy Clin Immunol 2011;128(5):927-34.

7) Oyer SL, Mulligan JK, Psaltis AJ, Henriquez OA, Schlosser RJ. Cytokine correlation between sinus tissue and nasal secretions among chronic rhinosinusitis and controls. Laryngoscope 2013;123(12): E72-8.

8) Cao PP, Li HB, Wang BF, Wang SB, You XJ, Cui YH, et al. Distinct immunopathologic characteristics of various types of chronic rhinosinusitis in adult Chinese. J Allergy Clin Immunol 2009; 124(3):478-84,

9) Tokunaga T, Sakashita M, Haruna T, Asaka D, Takeno S, Ikeda H, et al. Novel scoring system and algorithm for classifying chronic rhinosinusitis: The JESREC Study. Allergy 2015;70(8):995-1003.

10) Wen W, Liu W, Zhang L, Bai J, Fan Y, Xia W, et al. Increased neutrophilia in nasal polyps reduces the response to oral corticosteroid therapy. J Allergy Clin Immunol 2012;129(6):1522-8.e5.

11) Ho J, Bailey M, Zaunders J, Mrad N, Sacks R, Sewell W, et al. Group 2 innate lymphoid cells (ILC2s) are increased in chronic rhinosinusitis with nasal polyps or eosinophilia. Clin Exp Allergy 2015;45(2):394-403.

12) Tojima I, Kouzaki H, Shimizu S, Ogawa T, Arikata M, Kita H, et al. Group 2 innate lymphoid cells are increased in nasal polyps in patients with eosinophilic chronic rhinosinusitis. Clin Immunol 2016;170:1-8. 
13) Bachert C, Gevaert P, Hellings P. Biotherapeutics in chronic rhinosinusitis with and without nasal polyps. J Allergy Clin Immunol Pract 2017;5(6):1512-6.

14) Gevaert P, Bachert C, Holtappels G, Novo CP, Van der Heyden J, Fransen L, et al. Enhanced soluble interleukin-5 receptor alpha expression in nasal polyposis. Allergy 2003;58(5):371-9.

15) Bachert C, Zhang N, Holtappels G, De Lobel L, van Cauwenberge $\mathrm{P}$, Liu S, et al. Presence of IL-5 protein and IgE antibodies to staphylococcal enterotoxins in nasal polyps is associated with comorbid asthma. J Allergy Clin Immunol 2010;126(5):962-8.

16) Gevaert P, Calus L, Van Bruaene N, Van Zele T, Bachert C. Allergic sensitization, high local IL-5 and IgE predict surgical outcome 12 years after endoscopic sinus surgery for chronic rhinosinusitis with nasal polyposis. J Allergy Clin Immunol 2015; 135(2):AB238.

17) Van Zele T, Holtappels G, Gevaert P, Bachert C. Differences in initial immunoprofiles between recurrent and nonrecurrent chronic rhinosinusitis with nasal polyps. Am J Rhinol Allergy 2014;28(3): 192-8.

18) Tomassen P, Vandeplas G, Van Zele T, Cardell LO, Arebro J, Olze $\mathrm{H}$, et al. Inflammatory endotypes of chronic rhinosinusitis based on cluster analysis of biomarkers. J Allergy Clin Immunol 2016; 137(5):1449-56.e4.

19) Gevaert $P$, Lang-Loidolt $D$, Lackner A, Stammberger $H$, Staudinger $\mathrm{H}$, Van Zele T, et al. Nasal IL-5 levels determine the response to anti-IL-5 treatment in patients with nasal polyps. J Allergy Clin Immunol 2006;118(5):1133-41.

20) Gevaert P, Van Bruaene N, Cattaert T, Van Steen K, Van Zele T, Acke F, et al. Mepolizumab, a humanized anti-IL-5 mAb, as a treatment option for severe nasal polyposis. J Allergy Clin Immunol 2011;128(5):989-95.e1-8.

21) Bachert C, Mannent L, Naclerio RM, Mullol J, Ferguson BJ, Gevaert P, et al. Effect of subcutaneous dupilumab on nasal polyp burden in patients with chronic sinusitis and nasal polyposis: A randomized clinical trial. JAMA 2016;315(5):469-79.

22) Kato A. Immunopathology of chronic rhinosinusitis. Allergol Int 2015;64(2):121-30.

23) Lam EP, Kariyawasam HH, Rana BM, Durham SR, McKenzie AN, Powell N, et al. IL-25/IL-33-responsive TH2 cells characterize nasal polyps with a default TH17 signature in nasal mucosa. J Allergy Clin Immunol 2016;137(5):1514-24.

24) Mjösberg JM, Trifari S, Crellin NK, Peters CP, van Drunen CM, Piet B, et al. Human IL-25- and IL-33-responsive type 2 innate lymphoid cells are defined by expression of CRTH2 and CD161. Nat Immunol 2011;12(11):1055-62.

25) Shaw JL, Fakhri S, Citardi MJ, Porter PC, Corry DB, Kheradmand $\mathrm{F}$, et al. IL-33-responsive innate lymphoid cells are an important source of IL-13 in chronic rhinosinusitis with nasal polyps. Am J Respir Crit Care Med 2013;188(4):432-9.

26) Kim DK, Jin HR, Eun KM, Mo JH, Cho SH, Oh S, et al. The role of interleukin-33 in chronic rhinosinusitis. Thorax 2017;72(7):635-45.

27) Gauvreau GM, O'Byrne PM, Boulet LP, Wang Y, Cockcroft D, Bigler J, et al. Effects of an anti-TSLP antibody on allergen-induced asthmatic responses. N Engl J Med 2014;370(22):2102-10.

28) Lam M, Hull L, McLachlan R, Snidvongs K, Chin D, Pratt E, et al. Clinical severity and epithelial endotypes in chronic rhinosinusitis. Int Forum Allergy Rhinol 2013;3(2):121-8.

29) Nagarkar DR, Poposki JA, Tan BK, Comeau MR, Peters AT, Hulse $\mathrm{KE}$, et al. Thymic stromal lymphopoietin activity is increased in nasal polyps of patients with chronic rhinosinusitis. J Allergy Clin
Immunol 2013;132(3):593-600.e12.

30) Reh DD, Wang Y, Ramanathan M Jr, Lane AP. Treatmentrecalcitrant chronic rhinosinusitis with polyps is associated with altered epithelial cell expression of interleukin-33. Am J Rhinol Allergy 2010;24(2):105-9.

31) Li W, Gao P, Zhi Y, Xu W, Wu Y, Yin J, et al. Periostin: Its role in asthma and its potential as a diagnostic or therapeutic target. Respir Res 2015;16:57.

32) Kim DW, Kulka M, Jo A, Eun KM, Arizmendi N, Tancowny BP, et al. Cross-talk between human mast cells and epithelial cells by IgE-mediated periostin production in eosinophilic nasal polyps. J Allergy Clin Immunol 2017;139(5):1692-5.e6.

33) Hanania NA, Wenzel S, Rosén K, Hsieh HJ, Mosesova S, Choy $\mathrm{DF}$, et al. Exploring the effects of omalizumab in allergic asthma: an analysis of biomarkers in the EXTRA study. Am J Respir Crit Care Med 2013;187(8):804-11.

34) Hulse KE, Norton JE, Suh L, Zhong Q, Mahdavinia M, Simon P, et al. Chronic rhinosinusitis with nasal polyps is characterized by B-cell inflammation and EBV-induced protein 2 expression. J Allergy Clin Immunol 2013;131(4):1075-83.

35) Tan BK, Li QZ, Suh L, Kato A, Conley DB, Chandra RK, et al. Evidence for intranasal antinuclear autoantibodies in patients with chronic rhinosinusitis with nasal polyps. J Allergy Clin Immunol 2011;128(6):1198-1206.e1.

36) Gevaert P, Holtappels G, Johansson SG, Cuvelier C, Cauwenberge $\mathrm{P}$, Bachert C. Organization of secondary lymphoid tissue and local IgE formation to Staphylococcus aureus enterotoxins in nasal polyp tissue. Allergy 2005;60(1):71-9.

37) Van Zele T, Gevaert P, Holtappels G, van Cauwenberge P, Bachert C. Local immunoglobulin production in nasal polyposis is modulated by superantigens. Clin Exp Allergy 2007;37(12):1840-7.

38) Suh KS, Park HS, Nahm DH, Kim YK, Lee YM, Park K. Role of $\operatorname{IgG}$, IgA, and IgE antibodies in nasal polyp tissue: Their relationships with eosinophilic infiltration and degranulation. J Korean Med Sci 2002;17(3):375-80.

39) Hulse KE, Stevens WW, Tan BK, Schleimer RP. Pathogenesis of nasal polyposis. Clin Exp Allergy 2015;45(2):328-46.

40) Gevaert P, Calus L, Van Zele T, Blomme K, De Ruyck N, Bauters $\mathrm{W}$, et al. Omalizumab is effective in allergic and nonallergic patients with nasal polyps and asthma. J Allergy Clin Immunol 2013; 131(1):110-6.e1.

41) Kato A, Peters A, Suh L, Carter R, Harris KE, Chandra R, et al. Evidence of a role for B cell-activating factor of the TNF family in the pathogenesis of chronic rhinosinusitis with nasal polyps. J Allergy Clin Immunol 2008;121(6):1385-92.

42) Wang X, Zhang N, Bo M, Holtappels G, Zheng M, Lou H, et al. Diversity of TH cytokine profiles in patients with chronic rhinosinusitis: A multicenter study in Europe, Asia, and Oceania. J Allergy Clin Immunol 2016;138(5):1344-53.

43) Liao B, Liu JX, Li ZY, Zhen Z, Cao PP, Yao Y, et al. Multidimensional endotypes of chronic rhinosinusitis and their association with treatment outcomes. Allergy 2018;73(7):1459-69.

44) Kim DK, Kang SI, Kong IG, Cho YH, Song SK, Hyun SJ, et al. Two-track medical treatment strategy according to the clinical scoring system for chronic rhinosinusitis. Allergy Asthma Immunol Res 2018;10(5):490-502.

45) Kim JW, Huh G, Rhee CS, Lee CH, Lee J, Chung JH, et al. Unsupervised cluster analysis of chronic rhinosinusitis with nasal polyp using routinely available clinical markers and its implication in treatment outcomes. Int Forum Allergy Rhinol 2019;9(1):79-86. 
Korean J Otorhinolaryngol-Head Neck Surg I 2019;62(8):427-34

\section{정답 및 해설}

답 (1)

해 설 비골골절과 비중격골절이 동반되었을 경우에는 asch foecep을 이용하여 좋은 결과를 얻을 수 있다. 참고문헌: 대한이비인후과학회. 이비인후과학-두경부외과학. 개정2판. 서울: 일조각;2009. p.1391. 